\title{
TECHNETIUM CHEMISTRY, OXIDATION STATES AND SPECIES
}

\author{
C. L. Rulfs, R. A. PACER and R. F. HiRsch \\ Department of Chemistry, The University of Michigan, Ann Arbor, Michigan
}

(Received 14 July 1966)

\begin{abstract}
Pertechnetic and perrhenic acids behave as very strong acids, $K_{\mathrm{a}} \sim 10^{8}$. Their extensive dehydration to $\mathrm{M}_{2} \mathrm{O}_{7}$ in such media as $7 \mathrm{M}$ sulphuric acid complicates a spectrophotometric comparison of acid strengths. Chloroform extractable $\mathrm{TcO}_{\mathrm{s}} \mathrm{Cl}$ forms from pertechnetate in the presence of chloride ion and concentrated sulphuric acid. The (VII) state of this compound is confirmed and its spectrum described. No evidence of unusual technetium (VII) species, in aqueous media of $1 \mathrm{~N}$ base to $1 \mathrm{~N}$ acid, has been found. The red colour of concentrated aqueous $\mathrm{HTcO}_{4}$ is ascribed to a lower (VI) or (V) state. The existence in alkaline media of a technetate, $\mathrm{TcO}_{4}{ }^{2-}$, species has been re-examined. Some (IV) and (III) state species are partially characterized, but no $\mathrm{Tc}_{2} \mathrm{O}_{3}$ could be isolated.
\end{abstract}

\section{INTRODUCTION}

WHILE the chemistry of technetium closely parallels that of rhenium, any distinctions of behaviour in the sequence $\mathrm{Mn}-\mathrm{Tc}-\mathrm{Re}$ are of great interest. A chronological comparison of recent summaries of technetium chemistry ${ }^{(1-5)}$ shows this to be a rather active area of study.

The results of the present study are described in sections associated with species and oxidation states. The conventional techniques and equipment employed are described very concisely. Further detail is available in two recent theses. ${ }^{(6.7)}$

\section{EXPERIMENTAL}

Reagents. All technetium-99 material was obtained from the Oak Ridge National Laboratory, either as technetium metal powder or as ammonium pertechnetate solutions. Gravimetric or spectrophotometric assays were used to define solution concentrations. The material is of good purity; d.c.-arc emission and X-ray fluorescence spectra of the metal indicated the presence of only $40 \mathrm{ppm}$ of $\mathrm{Cu}, 20 \mathrm{ppm} \mathrm{Ru}, 60 \mathrm{ppm} \mathrm{Y}$ and $20 \mathrm{ppm} \mathrm{Zr}$. Some oxide coating, moisture and some sodium, are also present, but these are not disadvantageous for most types of experimentation.

Technetium heptoxide was prepared by combustion of the metal in a stream of pure oxygen. The material was passed through three successive traps, (1) dry or containing distilled water (if $\mathrm{HTcO}_{4}$ was desired), cooled in ice-water, (2) dry trap cooled by dry ice-isopropanol bath, (3) safety trap of $1 \mathrm{M}$ sodium hydroxide (only traces of activity ever reach this trap). A residual 5 per cent

(1) G. E. BoYD, J. Chem. Educ. 36, 3 (1959).

(2) E. ANDERs, The Radiochemistry of Technetium, Nuclear Science Series 3021. National Academy of Science, National Research Council, Washington (1960).

(3) J. W. Cosble, Analytical Chemistry of Technetium, Part II, Chap. 43 Treatise on Analytical Chemistry (Edited by I. M. Kolthorf and P. J. Elving). Interscience, New York (1964).

(4) R. Colton and R. D. Peacock, Q. Rev. chem. Soc. 16, 299 (1962); R. Colton, The Chemistry of Rhenium and Technetium. J. Wiley, London (1965).

(5) K. Schwochau, Angew. Chem. 76, 9 (1964).

(6) R. A. PACER, Investigation of the Analytical Chemistry of Technetium, thesis, University of Michigan, Ann Arbor (1965).

(7) R. F. HIRsch, Some Analytical Aspects of the Chemistry of Technetium, thesis, University of Michigan, Ann Arbor (1965). 
or so of the metal tends to remain uncombusted in the boat, possibly due to a thin coating of sodium pertechnetate. This material is primarily technetium, but it may contain $0 \cdot 1$ per cent of sodium.

Rhenium heptoxide was obtained from the Department of Chemistry at the University of Tennessee.

All other chemicals were of CP or AR grade, and Spectrochemical Grade solvents were used.

Optical measurements. Beckman Model DU and DB spectrophotometers as well as the Cary Model 11 were used. Both 5-cm and 1-cm silica cells were used, and the Limit Research Corp. UVO $0.01-0.2-\mathrm{mm}$ cells were used in the Beer's Law studies. A Perkin-Elmer Model 137 Infracord was used for a few measurements.

A Schmidt and Haensch polarimeter was used with a sodium lamp and a 10-cm capillary cell requiring less than $2 \mathrm{ml}$ of solution.

Electrochemical equipment. A Beckman Model G pH meter, a Fisher Elecdropode and a Fisher Powerhouse were used. The two latter items were components of a gas coulometer assembly, described elsewhere. ${ }^{(B)}$

Radiochemical counting. Evaporated aliquots on small planchets were sometimes counted with a thin-wall Geiger tube and Nuclear-Chicago 151-A decade scaler. A Packard Tri-Carb 314 F scintillation counter was also used, operating on coincidence mode in integral position with the minimum counting window set just above electronic noise level. The counting solution contained $0.3 \mathrm{~g}$ dimethyl-POPOP, $7 \mathrm{~g}$ PPO and $100 \mathrm{~g}$ naphthalene per kilogram of dioxane.

\section{Pertechnetic acid}

\section{RESULTS}

Potentiometric neutralimetry. The acid, $\mathrm{HTcO}_{4}$, has long been described, on the basis of potentiometric neutralimetry, ${ }^{(9)}$ as being monobasic and strong. ${ }^{(3)}$ There is little evidence for the existence of a meso form, analogous with $\mathrm{H}_{3} \mathrm{ReO}_{5},{ }^{(10)}$ in other than strongly alkaline media. Based on the liquid-liquid extraction behaviour of their TBP complexes, KERTES and BECK infer the possibility that $\mathrm{HReO}_{4}$ is stronger than $\mathrm{HTcO}_{4}$. ${ }^{\text {(1) }}$

A series of $0.23 \mathrm{M}$ to $0.01 \mathrm{M}$ solutions of $\mathrm{HTcO}_{4}$ thermostatted at $25^{\circ} \mathrm{C}$ were titrated with approximately equivalent concentrations of carbonate-free $\mathrm{NaOH}$. The apparent $K_{\mathrm{a}}$ values were calculated from stoicheiometrically-deduced concentrations of the acid and the base forms and from the $\mathrm{pH}$ readings during the course of the titration. The calculated $K_{\mathrm{a}}$ value decreased from 0.9 for $0.23 \mathrm{M}$ solutions and 0.5 for $0.1 \mathrm{M}$ to about 0.1 using $0.01 \mathrm{M}$ solutions. Such behaviour is almost indistinguishable from that observed with either $\mathrm{HCl}$ or $\mathrm{HReO}_{4}$ solutions, and the true ionization constant of $\mathrm{HTcO}_{4}$ is too high to permit any discrimination by this means.

Spectrophotometric method. In the case of a number of $\mathrm{XO}_{4}$ ions, such as $\mathrm{CrO}_{4}{ }^{2-}$, $\mathrm{MnO}_{4}^{-}, \mathrm{ReO}_{4}{ }^{-}$and $\mathrm{VO}_{4}{ }^{3-}$, CARRINGTON and SYMONS et al. ${ }^{(\mathbf{1 2 , 1 3 )}}$ calculate ionization constants for the corresponding acids based upon the spectral differences found between solutions of their neutral salts and in media containing increasing concentrations of added $\mathrm{H}_{2} \mathrm{SO}_{4}$ or $\mathrm{HClO}_{4}$. As strong acid is added to these systems the lower wavelength absorptions tend to decrease while a weak new absorption, which is ascribed to the protonated form, appears at longer wavelength. The significant change is ascribed to the reduction of tetrahedral $T_{d}$ symmetry to $C_{3 v}$ for a $\mathrm{YXO}_{3}$ species.

\footnotetext{
(8) G. B. S. Salaria, C. L. Rulfs and P. J. Elving, Analyt. Chem. 35, 979 (1963).

(9) J. W. Cobble, Doctoral thesis, University of Tennessee (1952).

(10) B. Scharnow, $Z$. anorg. allg. Chem. 215, 185 (1933).

(11) A. S. Kertes and A. Beck, Proc. 7th Int. Conf. Co-ordination Chem. Stockholm, 352 (June 1962).

(12) N. Bailey, A. Carrington, K. A. Lott and M. C. Symons, J. chem. Soc. 290 (1960).

(18) A. Carrington and M. Symons, Chem. Rev. 63, 443 (1963).
} 
The assumption that condensations (or, dimerization and dehydration) such as,

$$
2 \mathrm{CrO}_{4}{ }^{2-}+2 \mathrm{H}^{+}=\mathrm{Cr}_{2} \mathrm{O}_{7}^{2-}+\mathrm{H}_{2} \mathrm{O} \text {, }
$$

are not observed appears to be based on constancy of molar absorptivities over a four-fold range of $\mathrm{Cr}(\mathrm{VI})$ concentration. ${ }^{(14)}$ Consistency of the results in $\mathrm{HClO}_{4}$ is taken to imply that the dehydrating potency of sulphuric acid, formation of sulphate salts, etc. does not invalidate the technique. In our attempts to apply this method to $\mathrm{HTcO}_{4}$ the system does not appear to behave as anticipated, and the need for further study and a re-examination of the $\mathrm{HReO}_{4}$ system became obvious.

The behaviour of pertechnetate in perchloric acid is similar to its behaviour in the same molarities of sulphuric acid; the changes in absorbance at the peak wavelength are comparable. The peak at $2875 \AA$, present in a neutral solution of $\mathrm{NH}_{4} \mathrm{TcO}_{4}$ (Fig. 1), remains unchanged for perchloric or sulphuric acid concentrations below

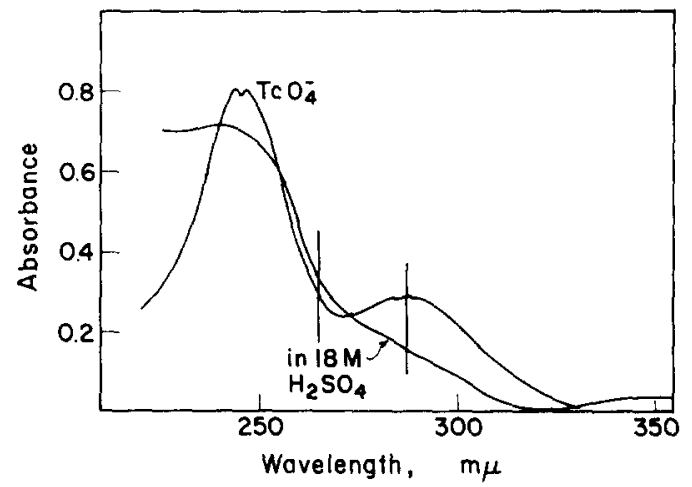

FIG. 1.-Absorption spectra of pertechnetate ion, in neutral solution and in concentrated sulphuric acid.

about $7 \mathrm{M}$. The peak gradually disappears with increasing acid concentration, the half-way point being reached at an acid concentration of about $9.4 \mathrm{M}$. The new peak at $3400 \AA$ is weak, broad, and difficult to resolve because of the overlap from the more intense peak at $2875 \AA$. The absorbance at $3400 \AA$ appears to be negligible and constant until an acid concentration of about $7 \mathrm{M}$ is reached; then it increases until an acid concentration of about $11 \mathrm{M}$ is reached. The absorbance of the peaks at 2440 and $2480 \AA$ seems to be strongly influenced by the growth of a new band at lower wavelength with increasing acid concentration.

The situation is more complicated for perrhenate than with pertechnetate. The variation in absorbances in perchloric acid are much less prominent than those in the sulphuric acid series. The new absorbance at $2850 \AA$ arises with increasing concentration of sulphuric acid, starting from about $8 \mathrm{M}$, reaching the midpoint at about $12 \mathrm{M}$, and showing maximum development at about $15 \mathrm{M}$. The set of peaks around $2250 \AA$ appears to merge with the main peak at $2080 \AA$, with the maximum absorbance in the most concentrated sulphuric acid solutions shifted to about $2120 \AA$. No

(14) F. Daniels et al. Experimental Physical Chemistry, (5th Edn) pp. 133-7. McGraw-Hill, New York (1956). 
decrease is found, however, as with pertechnetate and as reported by SYMON's group. ${ }^{(12)}$ The half-way point in the increase at $2100-2500 \AA$ is reached at an acid concentration of about $12.5 \mathrm{M}$.

With allowance for the "overlap" corrections, the new high-wavelength peaks of both the pertechnetate and the perrhenate "acid-species" appear to cut the lower wavelength features at an approximately constant, or isosbestic point (3200 $\AA$ for $\mathrm{TcO}_{4}^{-}$, and $2500 \AA$ with $\mathrm{ReO}_{4}^{-}$). This might be taken as indicative of the formation of a uniquely absorbing new species, but the argument is not strong.

It is significant that the absorbance changes reach the half-way point (i.e. the new high-wavelength peak reaches 50 per cent of its maximal value) in $9 \cdot 2 \mathrm{M}$ sulphuric acid for pertechnetate and in $12 \cdot 5 \mathrm{M}$ for perrhenate ion. This is the opposite of what would be predicted for a simple protonation reaction if the relative strengths of pertechnetic and perrhenic acids follow expectations from their positions in the periodic table. This suggests the alternative interpretation that the data obtained are related to some other equilibrium such as dimerization and dehydration. Both sulphuric and perchloric acids are effective dehydrating agents, and the spectrophotometric data suggest the presence of additional species.

Spectra were recorded for a series of pertechnetate and perrhenate solutions, varying the $\mathrm{Tc}(\mathrm{VII})$ and $\mathrm{Re}(\mathrm{VII})$ concentrations and holding the sulphuric acid concentration constant at the points of greatest spectral change $(9.5$ and $12.3 \mathrm{M}$, respectively) observed previously. For pertechnetate, the Beer's Law plots are straight lines within the precision of the measurements, but they do not cut the origin. For perrhenate, the plots are curved for all but $2500 \AA$ and the curvature is most marked in the more dilute concentration region and at longer wavelengths.

Both the 2440-2480 and the $2875 \AA$ peaks are attenuated for fresh $\mathrm{Tc}_{2} \mathrm{O}_{7}$ dissolved in dry dioxane under reasonably moisture-free conditions. The addition of small amounts of water produces a growth at these wavelengths, and the normal $\mathrm{TcO}_{4}^{-}$, spectrum reappears when the solution is made $1-3$ per cent in water. While the lower wavelength features of the $\mathrm{TcO}_{4}^{-}$curve in sulphuric acid include other contributions to the absorbance, the remainder of the curve is similar to that for $\mathrm{Tc}_{2} \mathrm{O}_{7}$ in dioxane. The absorbance ratio for neutral $\mathrm{TcO}_{4}-$ ion at $2650 \AA$ vs. $2875 \AA$ is unity, but for $\mathrm{Tc}_{2} \mathrm{O}_{7}$ in dioxane at these wavelengths it is $1 \cdot 9$, which compares with $2 \cdot 1$ for $\mathrm{Tc}$ (VII) in $18 \mathrm{M} \mathrm{H}_{2} \mathrm{SO}_{4}$.

The strength of sulphuric acid as a dehydrating agent is evident from the data shown in Table 1, and hydration data for the heptoxides ${ }^{(15)}$ permits the calculation of

TABLE 1.-STANDARD FREE ENERgY CHANGes FOR HYDRATIONS

\begin{tabular}{rr}
\hline Reaction & $\Delta F_{288}^{\circ}(\mathrm{cal})$ \\
\hline $\mathrm{H}_{2} \mathrm{SO}_{4} \cdot \mathrm{H}_{2} \mathrm{O}+\mathrm{H}_{2} \mathrm{O}=\mathrm{H}_{2} \mathrm{SO}_{4} \cdot 2 \mathrm{H}_{2} \mathrm{O}$ & -2884 \\
$\mathrm{H}_{2} \mathrm{SO}_{4} \cdot 2 \mathrm{H}_{2} \mathrm{O}+2 \mathrm{H}_{2} \mathrm{O}=\mathrm{H}_{2} \mathrm{SO}_{4} \cdot 4 \mathrm{H}_{2} \mathrm{O}$ & -3535 \\
$\mathrm{Tc}_{2} \mathrm{O}_{7}+\mathrm{H}_{2} \mathrm{O}=2 \mathrm{HTCO}_{4}$ & -1632 \\
$\mathrm{Re}_{2} \mathrm{O}_{7}+\mathrm{H}_{2} \mathrm{O}=2 \mathrm{HReO}_{4}$ & -2418 \\
$\mathrm{H}_{2} \mathrm{SO}_{4} \cdot \mathrm{H}_{2} \mathrm{O}+2 \mathrm{HReO}_{4}=\mathrm{H}_{2} \mathrm{SO}_{4} \cdot 2 \mathrm{H}_{2} \mathrm{O}+\mathrm{Re}_{2} \mathrm{O}_{7}$ & -466 \\
$\mathrm{H}_{2} \mathrm{SO}_{4} \cdot 2 \mathrm{H}_{2} \mathrm{O}+4 \mathrm{HReO}_{4}=\mathrm{H}_{2} \mathrm{SO}_{4} \cdot 4 \mathrm{H}_{2} \mathrm{O}+2 \mathrm{Re}_{2} \mathrm{O}_{7}$ & +1300 \\
$\mathrm{H}_{2} \mathrm{SO}_{4} \cdot \mathrm{H}_{2} \mathrm{O}+2 \mathrm{HTcO}_{4}=\mathrm{H}_{2} \mathrm{SO}_{4} \cdot 2 \mathrm{H}_{2} \mathrm{O}+\mathrm{Tc}_{2} \mathrm{O}_{7}$ & -1252 \\
$\mathrm{H}_{2} \mathrm{SO}_{4} \cdot 2 \mathrm{H}_{2} \mathrm{O}+4 \mathrm{HTcO}_{4}=\mathrm{H}_{2} \mathrm{SO}_{4} \cdot 4 \mathrm{H}_{2} \mathrm{O}+2 \mathrm{Tc}_{2} \mathrm{O}_{7}$ & -271 \\
\hline
\end{tabular}

(15) W. T. Smith, V. W. Cobrle and G. E. Boyd, J. Am. chem. Soc. 75, 5773 (1953). 
the last four values listed. Pertechnetic acid should be more easily dehydrated than is perrhenic acid; an equimolar mixture of the di- and tetrahydrates of sulphuric acid (corresponding to about $10.5 \mathrm{M}$ acid) should dehydrate $\mathrm{HTcO}_{4}$, but not $\mathrm{HReO}_{4}$. This conforms with the observation that major spectral changes occur with lower concentrations of sulphuric acid for pertechnetate than for perrhenate ion.

The new high-wavelength feature in these systems may well be due to the postulated reduction in symmetry characterizing the protonated forms of these acids. ${ }^{(1)}$ For the two systems examined here, however, there is little question of the co-existence of competing equilibria and significant concentrations of additional species. The presence of the heptoxides reasonably accounts for most of the observed behaviour. Acid ionization constants greater than ten are indicated for $\mathrm{HReO}_{4}$ and $\mathrm{HTcO}_{4}{ }^{2}$, but any closer specification seems ill-advised.

Acid catalysis of sucrose hydrolysis. This technique ${ }^{(14)}$ and its limitations have been widely publicized and described. The present significance of the method lies in its presumed applicability for the differentiation of very strong acids. Glucose and fructose solutions were mixed with samples of perrhenic acid (about $1.5 \mathrm{M}$ ) to determine whether the acid would oxidize the product sugars and invalidate the results. The mixtures were placed in the polarimeter and no change in the angle of rotation was noticed over the course of an hour.

Using $3.65 \pm 0.04 \mathrm{M}$ acid solutions, we obtained rate constants of: $\mathrm{Cl}_{3} \mathrm{C} \cdot \mathrm{CO}_{2} \mathrm{H}$, $0.0191 ; \mathrm{HCl}, 0.145$; and $\mathrm{HReO}_{4}, 0.30 / \mathrm{min}$. With $1.84 \pm 0.01 \mathrm{M}$ acid solutions, the rate constants obtained were $\mathrm{HCl}, 0.026 ; \mathrm{HBr}, 0.40$; and $\mathrm{HReO}_{4}, 0.041$; the 95 per cent confidence range for the duplicate determinations in this set is \pm 0.001 for each value. Using $1.6 \mathrm{M}$ acid solutions with $0.3 \mathrm{M}$ sucrose, the rate constants of $\mathrm{HTcO}_{4}$, $\mathrm{HReO}_{4}$ and $\mathrm{HBr}$ were all $4.4 \pm 0.1 \times 10^{-2}$.

These results suggest that there is no sensible difference between the relative strengths of perrhenic and pertechnetic acids and that their ionization constant is comparable $\left(\sim 10^{9}\right)$ with that of hydrobromic acid. The real significance of ionization constants as large as these (certainly, in other than a rather ill-defined comparative sense) remains open to some serious questions.

\section{Aqueous Tc(VII) species}

Miscellaneous species. No evidence was found for the formation of any dimeric, or higher, species from $\mathrm{TcO}_{4}-$ in aqueous media ranging from $1 \mathrm{~N}$ in added acid through $1 \mathrm{~N}$ in base. The only notable extension of this statement is the apparent existence of technetium or rhenium as heptoxides in $>5 \mathrm{M}$ solutions of $\mathrm{HClO}_{4}$ or $\mathrm{H}_{2} \mathrm{SO}_{4}$, noted in Spectrometric method.

FONTEYNE's suggestion that anomalies in the Raman Spectra of concentrated solutions of perrhenate salts and $\mathrm{HReO}_{4}$ might be due to hexacoordinate species, ${ }^{(16)}$ has been rather fully refuted and explained by later workers. ${ }^{(17,18)}$ We had only progressed to a preliminary i.r. survey using simple instrumentation when BUSEY and KELLER published the results of an extensive i.r. and Raman study of $\mathrm{KTcO}_{4}, \mathrm{KReO}_{4}$ and related tungsten and molybdenum compounds. ${ }^{(19)}$ Briefly, these authors interpret their data to indicate some perturbation of tetrahedral $\mathrm{TcO}_{4}{ }^{-}$by water molecules.

(16) R. Fonteyne, Chem. Abstr. 32, 4076 (1938).

(17) H. H. ClaAssen and A. J. Zielen, J. chem. Phys. 22, 707 (1954).

(18) L. A. Woodward and H. L. Roberts, Trans, Faraday Soc. 52, 615 (1956).

(19) R. H. Busey and O. L. Keller, J. chem. Phys. 41, 215 (1964). 
The existence of $\mathrm{ReO}_{5}{ }^{3-}$ suggests a comparable possibility for technetium in strongly alkaline media. This system is now being studied, but it is apparent that the existence of aqueous $\mathrm{TcO}_{5}{ }^{3-}$ could be of little consequence in less alkaline media than about 2-3 $\mathrm{N}$ base.

"Red" species. Reports of a pinkish colouration in pertechnetate salts and of the pink to red colour on dissolution of the heptoxide in small volumes of water are familiar in the literature. The existence of an unorthodox (VII) species now seems to

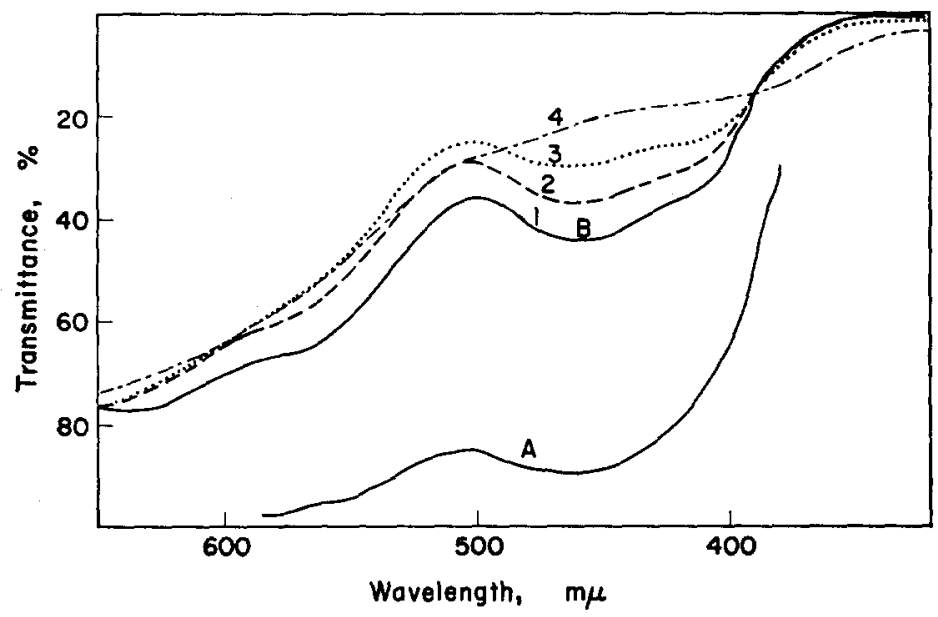

Fig. 2.-Possible technetium (VI) species. A, the red colour of $0.27 \mathrm{M} \mathrm{HTcO}$; $B$, progress of alkaline hydrazine reduction of pertechnetate to technetate after (1), 5 min;

(2), $40 \mathrm{~min}$; (3), $140 \mathrm{~min}$; (4), $10 \mathrm{hr}$.

be less favoured as an explanation than is the ascription of the colour to a small amount of (VI) or lower state. ${ }^{(3)}$ Rhenium trioxide is red, but a comparable technetium compound has not been isolated.

In the rigorous absence of reducing agents, the addition of concentrated $\mathrm{H}_{2} \mathrm{SO}_{4}$ to moderately concentrated pertechnetate solutions produced only a yellow colour absorbing below $4000 \AA$. This might be compared with yellow $\mathrm{Tc}_{2} \mathrm{O}_{7}$ or the broad absorbance of undissociated $\mathrm{HTCO}_{4}$ at $3400 \AA$ (Spectrometric method). The concentration of $30 \mathrm{ml}$ of $0.05 \mathrm{M} \mathrm{HTcO}_{4}$ to about $5 \mathrm{ml}$ gives a red-coloured $0.3 \mathrm{M}$ solution. The visible spectrum of this solution shows a broad maximum near $5000 \AA$ and strong absorption below $4000 \AA$, as in curve A of Fig. 2 .

On standing open to the dust and atmosphere $1 \mathrm{M}$ solutions of $\mathrm{HTcO}_{4}$ become lighter as black particles of $\mathrm{TcO}_{2}$ appear. Addition of $\mathrm{NaOH}$ to the red liquid gives an immediate brown precipitate. Dilution with water gives faint red-brown suspensions. Titration of deep red solutions with standard Ce(IV) indicated that up to 32 per cent of the (VII) was reduced if (VI) is assumed to be the reduction product. When a red concentrate is made red-brown by dilution, a $\mathrm{Ce}$ (IV) tiration first results in a deeper red (as $\mathrm{TcO}_{2}$ suspension oxidized to VI), and then becomes colourless.

These results are compatible with the interpretation that the red colour is due to a (VI) or a (V) state. Neutral $\mathrm{TcO}_{4}{ }^{-}$and dilute solutions of $\mathrm{HTcO}_{4}$ are quite stable, but 
solutions of $\mathrm{HTcO}_{4}$ more concentrated than about $0.2 \mathrm{M}$ may tend to decompose,

$$
2 \mathrm{H}_{2} \mathrm{O}+4 \mathrm{HTcO}_{4}=4 \mathrm{H}_{2} \mathrm{TcO}_{4}+\mathrm{O}_{2} \text {. }
$$

A concentrated solution of $\mathrm{HTcO}_{4}$ is also sufficiently strong as an oxidant to be sensitive to the presence of dust, organic vapours, etc. Other behaviour suggests that there usually follows the disproportionation,

$$
3 \mathrm{H}_{2} \mathrm{TcO}_{4} \text { (red) }=2 \mathrm{HTcO}_{4}+2 \mathrm{H}_{2} \mathrm{O}+\underline{\mathrm{TcO}_{2}} \text { (brown). }
$$

$\mathrm{MO}_{3} \mathrm{X}$, "per-yl" species. A number of examples of this type of compound have been shown to exist for manganese, technetium and rhenium. Among these are $\mathrm{ReO}_{3} \mathrm{~F},{ }^{(20)} \mathrm{ReO}_{3} \mathrm{Cl}^{(21,22)}, \mathrm{ReO}_{3} \mathrm{Br}^{(22)} \mathrm{TcO}_{3} \mathrm{~F},{ }^{(23)}$ and $\mathrm{TcO}_{3} \mathrm{Cl} .^{(21.5)}$

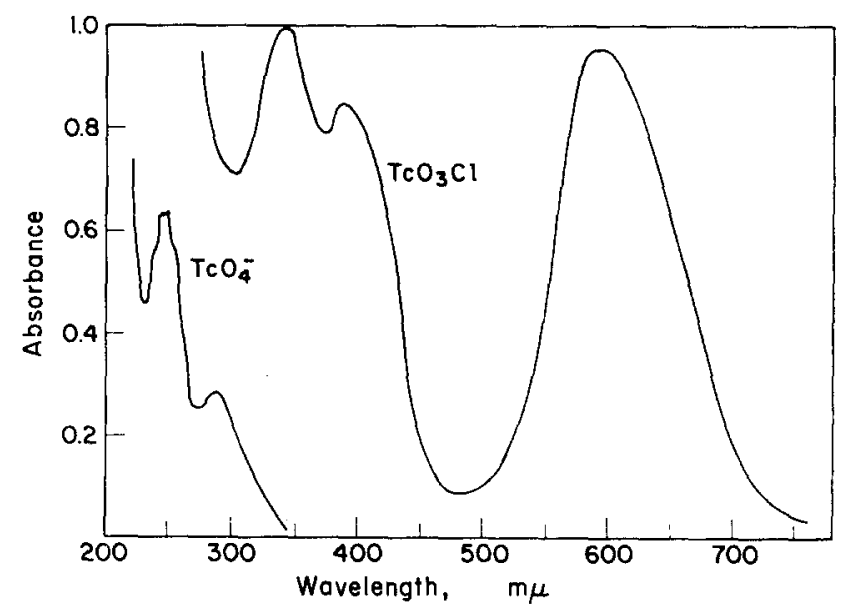

FIG. 3.-Pertechnetyl chloride absorption in chloroform solution $(1 \mathrm{~cm}, \sim 0.28 \mathrm{mM})$, compared with aqueous pertechnetate.

Pertechnetyl chloride may be prepared by adding small amounts of $12 \mathrm{M} \mathrm{HCl}$ to a cold dilute solution of pertechnetate in $18 \mathrm{M} \mathrm{H}_{2} \mathrm{SO}_{4}$. The resulting compound readily extracts into hexane, $\mathrm{CCl}_{4}$ or $\mathrm{CHCl}_{3}$. The material is moderately stable, but difficult to isolate. Little has been published on the spectrum or properties of this particular compound. BUSEY and LARSON ${ }^{(21)}$ claim that a dichloro species also exists, but that only the monochloride extracts into the organic layer.

The visible and some of the u.v. spectrum of $\mathrm{TcO}_{3} \mathrm{Cl}$ in chloroform is shown in Fig. 3, with a pertechnetate spectrum for comparison. The low-wavelength features are much shifted from those for pertechnetate, and the visible band(s) near $5950 \AA$ are unique.

Since the yield in this preparation in not high, it is not possible to estimate molar absorptivities on the basis of initial pertechnetate concentrations. It was found, however, that $\mathrm{TcO}_{3} \mathrm{Cl}$ in $\mathrm{CHCl}_{3}$ partitions back into $0 \cdot 1 \mathrm{~N}$ aqueous base about $1: 1$;

(20) A. Engelbrecht and A. V. Grosse, J. Am. chem. Soc. 76, 2042 (1954).

(21) R. H. Busey and Q. V. LARSon, U.S. Atomic Energy Commission Document ORNL-2159, 16 (1956).

(22) F. A. Miller and G. L. Carlson, Spectrochim. Acta 16, 1148 (1960).

(28) J. R. Sites, C. R. Baldock and L. O. Gilpatrick, U.S. Atomic Energy Commission Document ORNL, p. 1327 (1952). 
reverting to normal $\mathrm{TcO}_{4}^{-}$which may be measured spectrophotometrically. With successive back-extractions one is able to confirm that the technetium remains in the (VII) state, and it is possible to estimate the molar absorptivities of $\mathrm{TcO}_{3} \mathrm{Cl}$ in $\mathrm{CHCl}_{\mathbf{3}}$ as 3400 at $5950 \AA ; 3100$ at $3900 \AA$ and 3500 at $3450 \AA$.

Miscellaneous species transformations. As perhaps the most general test for possible aqueous $\mathrm{Tc}$ (VII) species transformations we have briefly examined the partitioning of $\mathrm{HTcO}_{4}$ into ether and made a rather extended "Beer's Law" study of aqueous $\mathrm{TcO}_{4}^{-}$. These techniques should be sensitive to the specific types of species previously mentioned, and should also detect the presence of other conceivable species.

Among the most extensive studies on the liquid-liquid extraction of $\mathrm{Tc}(\mathrm{VII})$, is the survey by BOYD and LARSON. ${ }^{(24)}$ The presence of a donor group (nitrogen or basic oxygen) in the organic molecule is favourable and extractions from acidic media appear to depend on formation of an "onium" salt. Prior studies have begun below $10^{-3} \mathrm{M}$ levels; it seemed to be worth checking the higher concentration level for a typical system.

The aqueous $\mathrm{HCl}$-diethylether system was examined over the range 0.8 to $5.6 \mathrm{~N}$ $\mathrm{HCl}$ (greater than $6 \mathrm{~N}$ leads to reduction of the Tc), and $2.4 \times 10^{-4}$ to $10^{-2} \mathrm{M}$ initial $\mathrm{TCO}_{4}^{-}$concentration. Distributions were determined by counting neutralized and evaporated aliquots from each phase. The volumes of both phases were measured before and after the 15-min equilibrations at room temperature. The experimental distribution coefficient was corrected for the solubility of ether in the aqueous phases. Table 2 indicates typical results.

TABle 2.-ETHER EXTRACTION OF $\mathrm{HTCO}_{4}$ From aQueOUS $\mathrm{HCl}$

\begin{tabular}{|c|c|c|c|c|}
\hline $\begin{array}{l}\mathrm{N} \text { aq. } \mathrm{HCl} \text {, } \\
\text { after equil. }\end{array}$ & \multicolumn{3}{|c|}{ Corr. $D$, for initial $\mathrm{HTcO}_{4}(\mathrm{mM})$} & $\begin{array}{c}D, \\
\text { average }\end{array}$ \\
\hline 0.73 & 0.04 & 0.03 & 0.03 & $0.03_{1}$ \\
\hline $1 \cdot 52$ & $0 \cdot 04$ & 0.05 & 0.07 & $0.05_{8}$ \\
\hline $2 \cdot 30$ & 0.06 & 0.09 & $0 \cdot 14$ & $0.09_{7}$ \\
\hline $3 \cdot 17$ & $0 \cdot 11$ & 0.17 & 0.13 & $0 \cdot 14$ \\
\hline $3 \cdot 88$ & $0 \cdot 14$ & 0.20 & $0 \cdot 14$ & $0 \cdot 16$ \\
\hline $4 \cdot 50$ & 0.14 & $0 \cdot 18$ & $0 \cdot 17$ & $0 \cdot 16$ \\
\hline
\end{tabular}

These data show only a gradual increase in $D$ as the acidity increases, which may be explained by the formation of an ion-association species like $\mathrm{Et}_{2} \mathrm{OH}^{+} \mathrm{TcO}_{4}^{-}$. But, within experimental error, there is no evidence of any significant trend in $D$ as a function of the pertechnetate concentration.

The u.v. absorption of a series of seventeen $0.158 \mathrm{mM}$ solutions of $\mathrm{TcO}_{4}^{-}$at $\mathrm{pH}$ 's from 0.35 to 12.2 were examined. No irregularities were found with either fresh or aged (up to several months) solutions, and the data will simply be summarized as they apply to the principal features of this familiar curve (see Figs. 1 and 3). For the doublet peaks at $244.3 \pm 0.3 \mathrm{~m} \mu$ and $248.1 \pm 0.3 \mathrm{~m} \mu$ molar absorptivities of $6148 \pm$ 67 and $6165 \pm 61$ are found; at $287.5 \pm 0.3 \mathrm{~m} \mu$ the absorptivity is $2316 \pm 33$.

The existence of a sizeable temperature coefficient of absorptivities would usually indicate a species-transition (except that simple hydration, as in meso-formation,

(2) G. E. BOYD and Q. V. LARson, J. phys. Chem. 64, 988 (1960). 
might have a small coefficient). Various $\mathrm{HTcO}_{4}$ solutions were examined at $10^{\circ}, 25^{\circ}$, $45^{\circ}$ and $60^{\circ} \mathrm{C}$. Molar absorptivities at points of maxima and minima seemed to remain constant within at least \pm 2 per cent.

Using cell paths varying from $0.01 \mathrm{~mm}$ to $5 \mathrm{~cm}$, twenty spectra were read on $\mathrm{TcO}_{4}^{-}$solution over the concentration range $1 \cdot 1 \times 10^{-5}$ to $0.18 \mathrm{M}$. The molar absorptivities agree with those found earlier, and the average of the ratio $\left(\epsilon_{244} / \epsilon_{287}\right)$ is the normal value of $2.66 \pm 0.03$ over this entire range. The effect of added acid or base up to $1 \mathrm{~N}$, and with ageing was also checked at various concentration levels of $\mathrm{Tc}$ (VII) and found to be negligible.

A less detailed examination of perrhenate was made for comparison. Spectra of $\mathrm{HReO}_{4}, \mathrm{NH}_{4} \mathrm{ReO}_{4}$ and $\mathrm{NaReO}_{4}$ solutions showed no abnormalities vs. pH. A Beer's Law study over the concentration range $10^{-4}-10^{-1} \mathrm{M}$ gave no evidence of any species transformation. There were no significant variation in the molar absorptivities of 6012 at $205 \mathrm{~m} \mu$ and 3530 at $227 \mathrm{~m} \mu$, and their average ratio was constant at $1.71 \pm 0.02$.

\section{Oxidation states below (VII)}

Technetate (VI) state. It is generally felt that a (VI) state such as $\mathrm{TcO}_{4}{ }^{2-}$ should likely be unstable in most aqueous media with respect to disproportionation to $\mathrm{TcO}_{2}$ and $\mathrm{TcO}_{4}-{ }^{-(3)}$ The technetate state may have a limited stability in alkaline media, analogous with the situation for manganate and rhenate.

GERLIT's work ${ }^{(25)}$ describes some co-precipitation behaviour and differences in extractability which suggest a (VI) state and distinguish it from the (VII) state. Hydrazine hydrate in cold alkaline media is claimed to reduce (VII) to this new state. Dilution to $<0.05 \mathrm{NaOH}^{-}$results in disproportionation leading, at equilibrium, to the expected ratio of about $2: 1$ of $\mathrm{Tc}(\mathrm{VII})$ to $\mathrm{Tc}(\mathrm{IV})$. The basis for this conclusion was not given.

A $\mathrm{Tc}$ (VI) species was prepared from $1.82 \mathrm{mM} \mathrm{TcO}_{4}^{-}, 0.015 \mathrm{M} \mathrm{N}_{2} \mathrm{H}_{4}$, and $0.7 \mathrm{M}$ $\mathrm{OH}^{-}$; and the growth and decay of the product was followed spectrophotometrically The reddish-brown product absorbs in the visible region at $500 \mathrm{~m} \mu$, with an $\epsilon$ of about 200 (estimated). An examination of both the visible (see Fig. 2) and the u.v. regions of the spectrum as a function of time shows an isosbestic point at $386 \mathrm{~m} \mu$. From 386 $\mathrm{m} \mu$ to about $650 \mathrm{~m} \mu$, the absorbance initially increases with time, due to formation of $\mathrm{Tc}(\mathrm{VI})$ at the expense of $\mathrm{Tc}(\mathrm{VII})$. Below $386 \mathrm{~m} \mu$ the absorbance decreases with time, due to the disappearance of $\mathrm{Tc}(\mathrm{VII})$.

$$
\begin{gathered}
\mathrm{TcO}_{4}^{-}+\mathrm{N}_{2} \mathrm{H}_{4}=\mathrm{TcO}_{4}^{2-}, \quad \text { followed by, } \\
3 \mathrm{TcO}_{4}^{2-}+2 \mathrm{H}_{2} \mathrm{O}=2 \mathrm{TcO}_{4}^{-}+\mathrm{TcO}_{2}+4 \mathrm{OH}^{-} .
\end{gathered}
$$

Any $\mathrm{TcO}_{2}$ is partially removed by centrifugation at intervals. The appearance of an isosbestic point is indicative of the presence of two interconvertible absorbing species, but the situation is complicated by the subsequent disproportionation reaction (2).

$\mathrm{Ba}(\mathrm{OH})_{2}$ was added to the hydrazine reduction product, taking precautions to avoid the formation of $\mathrm{BaCO}_{3}$. The impure grayish-pink precipitate was isolated and analysed to determine its barium to technetium ratio. The technetium was assayed by beta-counting, and the barium was estimated by separating $\mathrm{BaCrO}_{4}$ and measuring

(25) J. B. Gerum, Proc. Int. Conf. Peaceful Uses Atomic Energy, Geneva, Vol. 7, p. 145. United Nations (1955). 
the chromate colourimetrically. From these measurements approximate $\mathrm{Tc}$ to $\mathrm{Ba}$ mole ratios of $1 \cdot 2_{1}$ and $1 \cdot 1_{2}$ were obtained, indicating that the product is $\mathrm{BaTcO}_{4}$, rather than $\mathrm{Ba}_{3}\left(\mathrm{TcO}_{5}\right)_{2}(\mathrm{Tc} / \mathrm{Ba}=0.67)$ or $\mathrm{Ba}\left(\mathrm{TcO}_{4}\right)_{2}(\mathrm{Tc} / \mathrm{Ba}=2.0)$. The small amounts of material isolated may be contaminated with co-precipitated $\mathrm{TcO}_{2}$ and $\mathrm{Ba}\left(\mathrm{TcO}_{4}\right)_{2}$.

Technetium (IV) and (III) states. Coulometric reduction of a pertechnetate solution generally results in either a 3 or 4-electron reduction, depending on (1) $\mathrm{pH}$, (2) nature of the supporting electrolyte, and (3) applied potential. ${ }^{(8,26)}$ The 4-electron reduction results in either a green solution ${ }^{(8,27.28)}$ believed to be a $\mathrm{Tc}(\mathrm{III})$ complex species, or in a brown to black precipitate which could be the sesquioxide, $\mathrm{Tc}_{2} \mathrm{O}_{3}$. In view of the instability of uncomplexed Tc(III) solutions, it is also possible that the black precipitate is $\mathrm{TcO}_{2}$ resulting from a subsequent disproportionation or from air or solvent oxidation of the $\mathrm{Tc}$ (III).

The coulometric arrangements, involving a mercury pool cathode, external anode and gas coulometer, were similar to those described earlier. ${ }^{(8)}$ Pre-electrolysis, nitrogen saturation, precautions and corrections for $\mathrm{HTcO}_{4}$ volatilization and the acid-Hg reduction of pertechnetate have also been noted. Cyclic reoxidation of the (III) product by oxygen to, at least, the (IV) level can occur at a significant rate; the assumption that the background current is small and constant is valid only with careful exclusion of air.

In eight runs in $1 \mathrm{M} \mathrm{H}_{2} \mathrm{SO}_{4}$ at applied potentials of -0.25 to $-0.45 \mathrm{~V}$ vs. S.C.E., the average coulometric " $n$-value" for the (VII)/(III) reduction was 3.65 , against 3.85 from $\mathrm{Ce}(\mathrm{IV})$ titrations of the product-solution aliquots. In alkaline media (0.25 $\mathrm{M}$ $\mathrm{NaOH}$ at $-1.15 \mathrm{~V}$ ) only 3.46 was obtained by coulometry. TeRRY and ZITTEL ${ }^{(28)}$ have shown that this process in a (III)-complexing medium, such as phosphate at $\mathrm{pH}=4.7$ is reproducible, within $n=4.00 \pm 0.04$, or better. Even in $2 \mathrm{~N}$ acids, and especially in $\mathrm{H}_{2} \mathrm{SO}_{4}$ rather than $\mathrm{HCl}$, some tendency persists for the (IV)/(III) stage to remain separated from (more negative than) the (VII)/(IV) step. ${ }^{(26)}$ Our most negative run at $-0.45 \mathrm{~V}$ does give $n=3.90 \pm 0.05$ by coulometry and by titration. It is not possible to avoid some chemical reduction of $\mathrm{Tc}$ (VII) by the mercury, and this appears to account for most of the coulometric vs. titrimetric discrepancy.

Prolonged centrifugation did not lead to the separation of any $\mathrm{Tc}_{2} \mathrm{O}_{3}$ in the acidic runs. The addition of base leads to a brown-black precipitate $\left(\mathrm{TcO}_{2}\right.$ ?) as in the case of coulometry in basic media. Attempts to exclude air during such preparations (including washing and vacuum desiccating or low temperature drying), did not lead to very reproducible or pure products. Equivalent weights, by $\mathrm{Ce}$ (IV) titration and Tc assay of the products, were always high. The Tc assays ranged from 53 to 62 per cent. In one of seven such products the Tc assayed 50 per cent, with an equivalent weight of 60. The products were too amorphous to give good $\mathrm{X}$-ray patterns. The predominant product obtainable is evidently $\mathrm{TcO}_{2} \cdot 2 \mathrm{H}_{2} \mathrm{O}$; certainly little $\mathrm{Tc}_{2} \mathrm{O}_{3}$ (equiv. wt., 30-8) could have existed in the products.

Several articles ${ }^{(26-28)}$ have noted the formation of a green $\mathrm{Tc}(\mathrm{III})$ phosphate complex by coulometric reduction of $\mathrm{Tc}$ (VII) in phosphate buffer solutions of $\mathrm{pH}$

(26) G. B. S. Salaria, C. L. Rulfs and P. J. Elving, J. chem. Soc. 2479 (1963).

(17) H. H. Miller, M. T. KelleY and P. F. Thomason in Advances in Polarography (Edited by I. S. LONGMUTR), Vol. II. Pergamon Press, London (1960).

(28) A. A. Terry and H. E. ZTTTeL, Analyt. Chem. 35, 614 (1963). 
5-7. The absence of air and a long electrolysis time are requisite to obtain the product. In contact with air, the green solution becomes pink; analysis shows this to be a $\mathrm{Tc}$ (IV) phosphate complex.

This same green colour is formed when a dilute sulphuric acid solution of ferrous ammonium sulphate containing $\mathrm{H}_{3} \mathrm{PO}_{4}$ is contacted with $\mathrm{Tc}$ (VII). In the absence of $\mathrm{H}_{3} \mathrm{PO}_{4}$, the solution slowly darkens and $\mathrm{TcO}_{2}$ finally precipitates. On standing in air, the green-coloured product transforms to a yellow-orange species; the conversion is delayed by increasing the concentration of $\mathrm{H}_{3} \mathrm{PO}_{4}$.

The technetium activity of the yellow-orange species is largely retained by an anion exchange column and not by cation exchangers, while that of the green species is retained by neither. Since a cation exchange column removes the excess Fe(II) but neither form of the technetium, it was possible to determine " $n$-values" by titration with $\mathrm{KMnO}_{4}$. An $n$-value of $3 \cdot 16$ was obtained for reoxidation to (VII) of the yelloworange species, while a value of 3.88 was found for the green species. The visible spectra of these species are quite consistent with previous reports of green (III) and "pink" (IV) phosphate complexes. The characteristics of the phosphate complexes resulting from reductions with ferrous ion are,

\begin{tabular}{llll}
\hline Te(III) & Green & Uncharged & $\begin{array}{l}\epsilon \text { of } 250 \text { at } 595 \mathrm{~m} \mu \\
\epsilon \text { of } 140 \text { at } 500 \mathrm{~m} \mu\end{array}$ \\
\hline Te(IV) & Yellow-orange & Anionic & $\begin{array}{l}\epsilon \text { of } 1700 \text { at } 385 \mathrm{~m} \mu \\
\epsilon \text { of } 540 \text { at } 510 \mathrm{~m} \mu\end{array}$ \\
& &
\end{tabular}

Acknowledgements-The assistance of a National Science Foundation Cooperative Fellowship (R. A. P.) and support from a Michigan Memorial Phoenix Project Grant (R. F. H.) is gratefully acknowledged. Later stages of this work have been supported by the U.S. Atomic Energy Commission, Contract AT(11-1)-1483. 